Original Article

\title{
Persistent organic pollutants distribution in plasma lipoprotein fractions
}

\section{Distribuição persistente de poluentes orgânicos em frações de lipoproteínas plasmáticas}

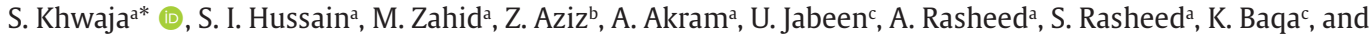 \\ A. Basit ${ }^{\mathrm{d}}$ \\ aFederal Urdu University of Arts, Science, and Technology, Department of Zoology,
}

Gulshan-e-Iqbal, Karachi, Pakistan

'Federal Urdu University of Arts, Science, and Technology, Department of Statistics,

Gulshan-e-Iqbal, Karachi, Pakistan

'Federal Urdu University of Arts, Science, and Technology, Department of Biochemistry,

Gulshan-e-Iqbal, Karachi, Pakistan

dBaqai Medical University, Karachi, Pakistan

\begin{abstract}
This study determines the associations among serum lipid profiles, risk of cardiovascular disease, and persistent organic pollutants. Using Gas chromatography technique, the intensity of toxic pollutant residues in serum samples of Hypertensive patients were measured. Based on statistical analysis, the effects of different covariates namely pesticides, age, systolic blood pressure, diastolic blood pressure, and lipid profile duration was checked using the logistic regression model. Statistical computation was performed on SPSS 22.0. The P-values of F-Statistic for each lipid profile class are greater than $0.01(1 \%)$, therefore we cannot reject the null hypothesis for all cases. The estimated coefficients, their standard errors, Wald Statistic, and odds ratio of the binary logistic regression model for different lipid profile parameters indicate if pesticides increase then the logit value of different lipid profile parameters changes from -0.46 to -0.246 except LDL which increases by 0.135 . The study reports a significantly increased threat of cardiovascular disease with increased concentrations of toxic pollutants.
\end{abstract}

Keywords: persistent organic pollutants, gas chromatography, cardiovascular diseases.

\begin{abstract}
Resumo
Este estudo determina as associações entre o perfil lipídico sérico, o risco de doença cardiovascular e os poluentes orgânicos persistentes. Por meio da técnica de cromatografia gasosa, mediu-se a intensidade dos resíduos de poluentes tóxicos em amostras de soro de pacientes hipertensos. Com base na análise estatística, os efeitos de diferentes covariáveis - ou seja, pesticidas, idade, pressão arterial sistólica, pressão arterial diastólica e duração do perfil lipídico - foram verificados usando o modelo de regressão logística. O cálculo estatístico foi realizado no SPSS 22.0. Os valores P da estatística F para cada classe de perfil lipídico são maiores que 0,01 (1\%), portanto não podemos rejeitar a hipótese nula para todos os casos. Os coeficientes estimados, seus erros padrão, estatística de Wald e odds ratio do modelo de regressão logística binária para diferentes parâmetros do perfil lipídico indicam se os pesticidas aumentam, então o valor logit de diferentes parâmetros do perfil lipídico muda de $-0,46$ para -0,246, exceto LDL, que aumenta em 0,135. 0 estudo relata um aumento significativo da ameaça de doença cardiovascular com aumento das concentrações de poluentes tóxicos.
\end{abstract}

Palavras-chave: poluentes orgânicos persistentes, cromatografia gasosa, doenças cardiovasculares.

\section{Introduction}

Cardiovascular diseases (CVD) are the main cause of mortality in developing countries. Primary risk factors of the cardiovascular disorder are high serum lipid levels, diet, sedentariness, hereditary circumstances, gender, smoking, hormone levels, and stress (Rehan et al., 2016; Anand et al., 2008).

The rate of CVD in developing countries is about 80\% (Yusuf et al., 2001). According to research noncommunicable illness will cause over $75 \%$ of deaths world wide by 2030. In developing countries, CVD will cause more deaths than other infectious diseases (Beaglehole and Bonita, 2008).

*e-mail: sobia.khwaja@fuuast.edu.pk; sobia.khawaja@hotmail.com

Received: February 19, 2021 - Accepted: May 31, 2021 
Research demonstrates that developing countries face an epidemic of CVD particularly in South Asia (Goenka et al., 2009). In 2020 CVD will cause more death and disability in India (Ahmad, 2002). Urbanization and aging contribute to increasing CVD rates (currently $12 \%$ of overall mortality) in Pakistan, which lost about one billion dollars from premature death caused by CVD and diabetes in 2005. In 2015 these diseases cost Pakistan about 31 billion dollars (WHO, 2013). In Pakistan, an individual gets a heart attack when his cholesterol level increases to about 150 milligrams while to Europeans it is 200 milligrams (Carpenter, 2008).

Several studies have demonstrated that numbers of chemicals exposure increase the frequency of CVD and this chemical comprises persistent organic pollutants, Polychlorinated biphenyls(PCBs), Organochlorine pesticides, Dioxins and Furans, Polybrominated diphenyl ethers (PBDEs) utilized as fire retardants and esters of Perfluorooctanoic acid (PFOEs), generally utilize in cleaning items (Park et al., 2005).

The recent rise in the use of Organochlorine pesticides (OCP) in Asia may be associated with the risk of metabolic syndrome (insulin resistance, dyslipidemia, and hypertension overweight also cardiovascular disease), a precursor of diabetes. This hazard considers measuring health issues for individuals (Frias et al., 2004). The main purpose of this study is to determine the POPs concentration in serum lipid profile and risk of cardiovascular diseases.

\section{Materials and Methods}

The current assessment was performed on the behalf of the Federal Urdu University of Arts, Science and Technology (FUUAST) Gulshan-e-Iqbal Campus Karachi during the period January to July 2018. For this purpose, we select fifty male and female hypertensive and high cholesterol patients. The convenient selection was done by the local inhabitants of Karachi city. A performa was planned to accumulate the complete information from the donors demonstrating their, name, age, and gender, nature of occupation confirmation of disease, or case study.

Blood samples were collected conveniently from individuals residing in different regions of Karachi to vacuum blood collection polypropylene tubes $(5 \mathrm{ml})$. The sera from the blood were then separated by centrifugation and were shifted into new blood tubes. Extraction of blood serum for residue analysis is done by Frias et al. 2004. Estimation of pesticides carried out by column chromatography (Frias et al., 2004).

Detection technique is the process by which determined the pesticide concentrations, with the help of a diagnostic instrument such as gas chromatography (GC). We observed pesticides concentration with reference to the original sample by running a standard solution having the pesticides at a known concentration and contrasting it with the sample. In current study data of POPs were analyzed including 16 agricultural organochlorine compounds and their metabolites $(\alpha-\mathrm{HCH}, \delta-\mathrm{HCH}, \gamma-\mathrm{HCH}, \beta-\mathrm{HCH}$, Heptachlor, Aldrin, Hepta-exo-epoxide, $\alpha$ - Endosulfan, DDE, Dieldrin, Endrin, $\beta$-Endosulfan, DDD, Endosulfan Sulfate, DDT,
Methoxychlor) and 7 Polychlorinated biphenyls (PCB- 28, 52,101, 138, 152, 180 and 209).

\subsection{Estimation procedure of lipid profile:}

For laboratory investigation of lipid profile parameter such as total cholesterol (TC) and triglycerides (TG) level estimation are carried out using enzymatic kit method, high density lipoprotein cholesterol (HDL-C) is estimated by precipitation of non HDL lipoprotein and estimation done using supernatant, and low density lipoprotein (LDL) cholesterol was calculated from the Friedewald formula (Formula 1):

$$
L D L-C=T C-H D L T G / 5.0[m g / d l]
$$

\subsection{Statistical analysis:}

\subsubsection{The model}

In this study, our statistical analysis is based on checking the effect of different covariates namely pesticides, age, systolic blood pressure (SBP), diastolic blood pressure (DBP), and duration on the lipid profile parameters. Our dependent variables i.e. lipid profile are measured on a binary scale which has been coded as 0 for normal level and 1 for a high or elevated level. To achieve this objective the logistic regression modeling is taken as the most suitable statistical technique when the response variable is measured on a nominal scale. This technique supplies the results in the log of odds, odds ratio, and probabilities which can support to present our objective of research very clearly. Our statistical computation is performed on the statistical package of IBM i.e. SPSS version 22.0. The binary logistic regression model using the aforementioned variables is expressed as (Equation 2).

$\log \left(\frac{P i}{1-P i}\right)=b_{0}+b_{1}$ pesticide $_{i}+b_{2} a_{3} e_{i}+b_{3} S B P_{i}+b_{4} D B P_{i}+b_{5}$ Duration $_{i}+e_{i}$

Where $\log \left(\frac{\boldsymbol{P i}}{1-\boldsymbol{P} \boldsymbol{i}}\right)$ is taken as a $\log$ of odds or link logit function while $\frac{\boldsymbol{P i}}{1-\boldsymbol{P i}}$ is considered the odds ratio. Odds ratio values explain the increase or decrease value of dependent variables in the presence of specific independent variables. Interpretation based on a log of odds and odds ratios is not easily understandable for non-Statistical background readers. To make it simple we show and interpret the probability of each lipid profile parameters with different covariates. The equation of probability derived from the model is stated as Equation 3:

$$
P i=\frac{1}{1+e^{-\left(\beta_{0}+\hat{a}_{1} \text { pesticide }_{\mathrm{i}}+\beta_{2} \text { age }_{\mathrm{i}}+\beta_{3} \mathrm{SBP}_{\mathrm{i}}+\beta_{4} \mathrm{DBP}_{\mathrm{i}}+\beta_{5} \text { Duration }_{\mathrm{i}}\right)}}
$$

We find out the association of lipid profile parameter such as TC, TG, LDL-C and HDL-C individually with all age 
groups by using one way variance analysis (ANOVA) on IBM SPSS Statistic Viewer Software.

One-way variance analysis estimated as (Equation 4):

$\mu_{23-32}=\mu_{33-42}=\mu_{43-53}$

We determine on average lipid profile parameters are equal or not in all age groups by using ANOVA analysis.

\subsubsection{Model diagnostics:}

We use Pseudo $\mathrm{R}^{2}$ as a goodness of fit criteria for the qualitative response regression model. It is employed to determine the percentage of an accurate number of predictions in total predictions. Hosmer-Lemeshow test is also applied to test the goodness of fit of the logistic regression model. The test statistic is based on the ChiSquare distribution.

\section{Results}

The result of the study is arranged into tables express with each variable. The outcome of the donor's serum pesticide residues was calculated in $\mathrm{mg} / \mathrm{kg}$. The finding of individual lipid profile parameters from blood samples is calculated in $\mathrm{mg} / \mathrm{dl}$. The dependent variables are total cholesterol (TC), triglycerides (TG), high-density lipoprotein cholesterol (HDL-C), and low-density lipoprotein cholesterol (LDL-C). Whereas, pesticides, age, diastolic blood pressure (DBP), systolic blood pressure (SBP), and duration are employed as the independent variables.

The industrial and agricultural pesticide residues ( $\mathrm{mg} /$ $\mathrm{kg}$ ) mean values of fifty blood donors' serum samples. The polychlorinated biphenyls was found in forty eight individual samples. The summation of PCBs is $0.071 \mathrm{mg} /$ kg. PCB-28, 52, 101, 138, 153, 180 and 209 are reported in samples as $40 \%, 34 \%, 18 \%, 18 \%, 44 \%, 26 \%$ and $12 \%$ respectively. However, the highest mean value of PCB180 is found in blood samples as $0.095 \mathrm{mg} / \mathrm{kg}$ although PCB-180 is found in thirteen people. On the other hand PCB mean values of 28,52,101,138, 153 and 209 are calculated as $0.0124 \mathrm{mg} / \mathrm{kg}, 0.0239 \mathrm{mg} / \mathrm{kg}, 0.0412 \mathrm{mg} / \mathrm{kg}, 0.0127 \mathrm{mg} /$ $\mathrm{kg}, 0.039 \mathrm{mg} / \mathrm{kg}$ and $0.027 \mathrm{mg} / \mathrm{kg}$ respectively.

The summation average values of organochlorine pesticides in serum sample is $0.169 \mathrm{mg} / \mathrm{kg}$. The isomers of $\mathrm{HCH}$ are $\alpha-\mathrm{HCH} 86 \%, \beta-\mathrm{HCH} 66 \%, \gamma-\mathrm{HCH} 30 \%$ and $\delta-\mathrm{HCH}$ is $30 \%$ were reported. Among these isomers $\beta-\mathrm{HCH}$ was found in forty three samples at higher $(0.121 \mathrm{mg} / \mathrm{kg})$ concentration. The mean value of other organochlorine pesticides such as Heptachlor is $0.093 \mathrm{mg} / \mathrm{kg}$ in eleven individual samples out of fifty. The mean value of Aldrin is $0.126 \mathrm{mg} / \mathrm{kg}$ and reported up to $76 \%$ while Endrin, $\alpha$ endosulfan, $\beta$-endosulfan, Endosulfan Sulfate and Dieldrin were investigated in fewer samples. The summation $(\Sigma)$ of Cyclodiene are found in forty six samples and the summation mean values is $0.225 \mathrm{mg} / \mathrm{kg}$. The derivatives of Dichlorodiphenyltrichloroethane (DDT) in blood serum are found in various concentration as 4,4-DDT (56\%), 4,4-DDE (50\%), 4,4-DDD (26\%).The Hexachlorobenzene is detected in only one sample. Diphenylaliphatic pesticides are found at $92 \%$ and the summation of pesticides is calculated as $0.149 \mathrm{mg} / \mathrm{kg}$.
We observed different percentages of high SBP and DBP in all age categories. By comparing SBP estimated values show decline trend such as $100 \%, 89 \%$ and $84 \%$ correspondingly in 23-32, 33-42 and 43-53 age groups. While DBP measurement also varies in all groups as $25 \%$ in younger, $47 \%$ in middle and $31 \%$ in older age group (Table 1 ).

Table 2 shows the ANOVA testing of different age groups for different lipid profile parameters. We test the equality of averages of lipid profile parameters such as TC, TG, LDL-C, and HDL-C individually with all age groups i.e. 23-32 years, 33-42 years, and 43-53 years by using oneway variance analysis (ANOVA). Our objective is to check whether the average lipid profile parameters are equal or not in all age groups. According to the reported results, the P-values of the F-Statistic for each lipid profile class is greater than 0.01 (1\%). It indicates that all F-statistics are highly significant so we cannot reject the null hypotheses for all cases. It implies that the age-wise average of each lipid profile parameters is equal. So findings suggest that cardiovascular disease patients of the age group from 23 to 53 years can have any abnormal value of lipid profile parameters. This ANOVA analysis support that there is no need to fit the binary logistic regression model age-wise. So we will not fit the model separately for different classes i.e. 23-32 years, 33-42 years, and 43-53 years. It means we will fit the model by taking all patients of different ages together in the analysis.

By comparing the lipid profile activity in all age groups.TC levels increase in middle age 33-42 as 78\% than slightly percentage decrease in older age 43-53 like $73 \%$ and youngest group has $66 \%$. In addition TG level are elevated at $91 \%$ in $23-32$ age people than $89 \%$ in $43-$ 53 group while $78 \%$ in 33-43 group. On the other hand 23-32 age group samples reported decline frequency of LDL-C approximating 50\% while remaining other two groups sample was estimated as 68\% elevated LDL-C. The proportion of HDL-C is extremely decrease (counter effect) in older age group $43-53$ as $42 \%$ and $41 \%$ in $23-32$ age group and $26 \%$ in middle age group (33-42).

In the end research findings suggest that TC level increases in following sequence $66 \%<73 \%<78 \%$ accordingly in 23-32 $<43-53<33-42$ age groups. Overall percentages of TG increase $91 \%$ in 23-32 group and then show decline trend $89 \%$ and $78 \%$ in $43-53$ and $33-42$ groups. The percentage

Table 1. Elevated lipid profile and blood pressure percentage in all age groups.

\begin{tabular}{cccc}
\hline $\begin{array}{c}\text { Elevated Lipid profile } \\
\text { and Blood pressure } \\
\text { percentages (\%) }\end{array}$ & $\begin{array}{c}\mathbf{2 3 - 3 2} \\
\text { Age } \\
\text { group }\end{array}$ & $\begin{array}{c}\mathbf{3 3 - 4 2} \\
\text { Age } \\
\text { group }\end{array}$ & $\begin{array}{c}\mathbf{4 3 - 5 3} \\
\text { Age } \\
\text { group }\end{array}$ \\
\hline TC & $66 \%$ & $78 \%$ & $73 \%$ \\
TG & $91 \%$ & $78 \%$ & $89 \%$ \\
LDL-C & $50 \%$ & $68 \%$ & $68 \%$ \\
HDL-C & $41 \%$ & $26 \%$ & $42 \%$ \\
SBP & $100 \%$ & $89 \%$ & $84 \%$ \\
DBP & $25 \%$ & $47 \%$ & $31 \%$ \\
\hline
\end{tabular}


of increase LDL-C and decrease HDL-C is $68 \%$ and $42 \%$ in older age group. However we observed 68\% and $26 \%$ raise LDL-C and lowest HDL-C in 33-42 age groups while 23-32 groups has 50\% and $41 \%$ cholesterol level alteration respectively as shown in Figure 1.

Table 3 reports the estimated coefficients, their standard errors, Wald statistic, and odds ratio of the binary logistic regression model for different lipid profile parameters. The table shows four models in which different lipid profile parameters are taken as dependent variables in binary classes. In all models, four independent variables namely pesticides, Age, SBP, DBP, and duration are employed. If we focus on the variable pesticide, the result shows that the coefficient of pesticides irrespective of sign in all models is higher than other independent variables overall the result is not significant on all parameters of lipid profile except LDL-C. It indicates that if pesticides increase then the logit value of different lipid profile parameters decreases from
-0.46 to -0.246 except LDL because it is increased by 0.135 . If age is increased by one year then the logit value of lipid profile parameters is also increased due to the positive value of coefficients although the magnitude of age variables is

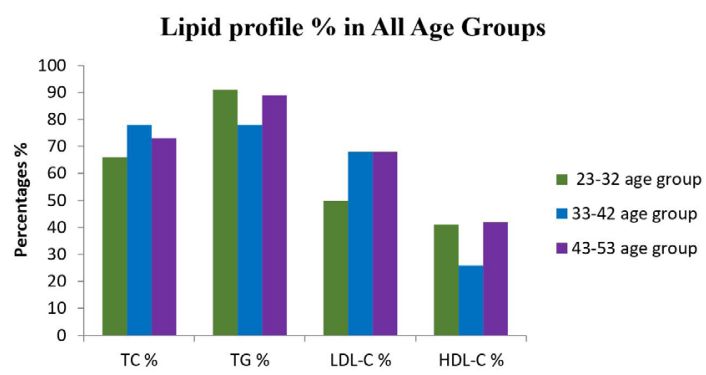

Figure 1. Bar graph showing complete lipid profile \% (TC, TG, LDL-C and $\mathrm{HDL}-\mathrm{C}$ ) in all age groups.

Table 2. ANOVA for testing the equality of different age groups for different lipid profiles.

\begin{tabular}{|c|c|c|c|c|c|c|c|}
\hline S.No & Variables & Null Hypothesis & $\begin{array}{l}\text { Alternative } \\
\text { Hypothesis }\end{array}$ & LOS & F-Statistic & P-value & Decision \\
\hline 1 & $\mathrm{TC}$ & $H_{0}=\mu_{23-32}=\mu_{33-42}=\mu_{43-53}$ & $\begin{array}{l}\text { At least Two Means } \\
\text { Are Not Equal }\end{array}$ & $1 \%$ & 0.811 & 0.450 & $\begin{array}{l}\text { Do Not } \\
\text { Reject }\end{array}$ \\
\hline 2 & TG & $H_{0}=\mu_{23-32}=\mu_{33-42}=\mu_{43-53}$ & $\begin{array}{l}\text { At least Two Means } \\
\text { Are Not Equal }\end{array}$ & $1 \%$ & 0.639 & 0.532 & $\begin{array}{l}\text { Do Not } \\
\text { Reject }\end{array}$ \\
\hline 3 & LDL-C & $H_{0}=\mu_{23-32}=\mu_{33-42}=\mu_{43-53}$ & $\begin{array}{l}\text { At least Two Means } \\
\text { Are Not Equal }\end{array}$ & $1 \%$ & 1.033 & 0.364 & $\begin{array}{l}\text { Do Not } \\
\text { Reject }\end{array}$ \\
\hline 4 & HDL-C & $H_{0}=\mu_{23-32}=\mu_{33-42}=\mu_{43-53}$ & $\begin{array}{l}\text { At least Two Means } \\
\text { Are Not Equal }\end{array}$ & $1 \%$ & 1.095 & 0.343 & $\begin{array}{l}\text { Do Not } \\
\text { Reject }\end{array}$ \\
\hline
\end{tabular}

Table 3. Estimated coefficients of binary logistic regression model for different lipid profile parameters.

\begin{tabular}{|c|c|c|c|c|c|c|c|c|}
\hline \multirow{2}{*}{$\begin{array}{c}\text { Model } \\
\text { No. }\end{array}$} & \multirow{2}{*}{\multicolumn{2}{|c|}{$\begin{array}{c}\text { Dependent Variable } \\
\text { Constant }\end{array}$}} & \multicolumn{6}{|c|}{ Independent Variables Group } \\
\hline & & & Pesticides & Age & SBP & DBP & Duration & \\
\hline \multirow[t]{4}{*}{1} & $\mathrm{TC}$ & Coefficient & 1.923 & -0.405 & 0.042 & -0.030 & 0.034 & -0.22 \\
\hline & & Standard Error & 4.679 & 0.505 & 0.049 & 0.039 & 0.054 & 0.309 \\
\hline & & Wald Statistic & 0.169 & 0.642 & 0.737 & 0.593 & 0.382 & 0.536 \\
\hline & & Odds Ratio & 6.839 & 0.667 & 1.043 & 0.970 & 1.034 & 0.797 \\
\hline \multirow[t]{4}{*}{2} & TG & Coefficient & 2.888 & -0.246 & 0.000 & -0.001 & -0.001 & -0.161 \\
\hline & & Standard Error & 5.704 & 0.611 & 0.060 & 0.049 & 0.068 & 0.385 \\
\hline & & Wald Statistic & 0.256 & 0.162 & 0.000 & 0.001 & 0.000 & 0.175 \\
\hline & & Odds Ratio & 17.954 & 0.782 & 1.000 & 0.999 & 0.999 & 0.852 \\
\hline \multirow[t]{4}{*}{3} & LDL-C & Coefficient & -2.552 & 0.135 & 0.071 & 0.002 & 0.015 & -0.374 \\
\hline & & Standard Error & 4.267 & 0.498 & 0.047 & 0.036 & 0.050 & 0.295 \\
\hline & & Wald Statistic & 0.358 & 0.074 & 2.335 & 0.005 & 0.096 & 1.604 \\
\hline & & Odds Ratio & 0.078 & 1.145 & 1.074 & 1.002 & 1.015 & 0.688 \\
\hline \multirow[t]{4}{*}{4} & HDL-C & Coefficient & 2.597 & -0.466 & 0.019 & -0.067 & 0.071 & 0.066 \\
\hline & & Standard Error & 4.273 & 0.501 & 0.048 & 0.038 & 0.052 & 0.294 \\
\hline & & Wald Statistic & 0.369 & 0.866 & 0.154 & 3.118 & 1.882 & 0.174 \\
\hline & & Odds Ratio & 13.427 & 0.627 & 1.019 & 0.935 & 1.073 & 1.131 \\
\hline
\end{tabular}


very low while it is zero in model 2. SBP is not associated with all lipid profile parameters except LDL whereas DBP has a positive impact on all lipid profile parameters except TG. It implies that when SBP increases the logit value of lipid profile parameters decreases except in the LDL-C case on the other hand when DBP increases the logit value increases except for the TG case. The duration variable shows the negative impact on all models except in model 4 in which HDL is taken as the dependent variable. So, it is interpreted that if the treatment duration of diseases is increased by one year then the logit value would be decreased except in the HDL-C case.

The interpretation of the logistic regression model in the logit link function is not easily understandable for the non-statistical reader. So logistic probabilities are also taken to interpret the chances of effect on the binary dependent variables. Logistic probabilities are calculated for each patient's information included in the data. But the interpretation of probability for each individual is laborious and non-practical. Therefore, we calculate the logistic probabilities on maximum, minimum, and average values of independent variables. Table 4 reports the logistic probabilities of four fitted binary logistic models on maximum, minimum, and average values of a group of independent variables. Table explores the probability $P$ in favor of benchmark category i.e. elevated level of lipid profile and (1-P) is the probability against the favor of benchmark category. To make it easy we interpret the probability of benchmark class which is coded for highlevel values of lipid profile parameters i.e. P.

Probabilities on maximum values of independent variables in a sample (pesticides $=$, Age $=, \mathrm{SBP}=, \mathrm{DBP}=$, Duration =,) are ranged from 0.780 to 0.921 for fitted models.
It implies that if the patient has the characteristics when all the independent variables values according to the used sample are maximum then the chances of that patient having an elevated level of lipid profile parameters are ranged from $78 \%$ to $92.1 \%$. If a patient has the characteristics when all the independent variables values are minimum according to given data then chances of that patient being elevated level of lipid profile parameters are $11.7 \%$ to $42.6 \%$. Similarly, if a patient has the characteristics when all the independent variables values are on average then chances of a patient in favor of having an elevated level of lipid profile parameters are ranged from $34.2 \%$ to $76.2 \%$. On the other hand, the (1-P) probability values can also be used to interpret the chances against the favor of having an elevated level. If we focus on individual models, then the chances to reach TG of a patient at an elevated level on average values of pesticides, age, SBP, DBP, and duration is higher than other dependent variables which $86.7 \%$.

Table 5 explores the diagnostics of the four fitted binary logistic regression models. Pseudo $\mathrm{R}^{2}$ and HosmerLemeshow Statistics with their P-values are reported in the table. According to the results, Pseudo $\mathrm{R}^{2}$ values are ranged from 0.139 to 0.014 . Although values of Pseudo $\mathrm{R}^{2}$ could be increased through incorporating the further independent variables and increasing the sample size. But due to the unavailability of data and the cost factor we cannot increase our independent variables and sample size easily. Hosmer-Lemeshow Statistic is significant at $1 \%$ level because the P-values of the Hosmer-Lemeshow test statistic is greater than the level of significance. So we do not reject the hypothesis that the model is well fitted.

Table 4. Logistics probabilities on maximum, minimum, and average values of independent variables.

\begin{tabular}{|c|c|c|c|c|c|c|c|}
\hline \multirow{3}{*}{ Model No. } & \multirow{3}{*}{ Dependent Variable } & \multicolumn{6}{|c|}{ Probabilities } \\
\hline & & \multicolumn{2}{|c|}{ Maximum } & \multicolumn{2}{|c|}{ Minimum } & \multicolumn{2}{|c|}{ Average } \\
\hline & & $\mathbf{P}$ & 1-P & $\mathbf{P}$ & 1-P & $\mathbf{P}$ & 1-P \\
\hline 1 & TC & 0.921 & 0.078 & 0.426 & 0.573 & 0.762 & 0.237 \\
\hline 2 & TG & 0.909 & 0.909 & 0.767 & 0.232 & 0.867 & 0.132 \\
\hline 3 & LDL-C & 0.837 & 0.1622 & 0.263 & 0.736 & 0.628 & 0.371 \\
\hline 4 & HDL-C & 0.780 & 0,219 & 0.117 & 0.882 & 0.342 & 0.657 \\
\hline
\end{tabular}

Table 5. Diagnostics of binary logistic regression modeling.

\begin{tabular}{ccccc}
\hline & & \multicolumn{2}{c}{ Model Diagnostics } \\
\cline { 3 - 4 } Model No. & Dependent Variable & Pseudo R & Hosmer-Lemeshow Statistic $\left(\chi^{2}\right)$ & P-Values $\left(\chi^{2}\right)$ \\
\hline 1 & TC & 0.045 & $7.910^{*}$ & 0.442 \\
2 & TG & 0.014 & $6.588^{*}$ & 0.582 \\
3 & LDL-C & 0.129 & $6.134^{*}$ & 0.632 \\
4 & HDL-C & 0.139 & $6.236^{*}$ & 0.620 \\
\hline
\end{tabular}

Policy = If P-value $>$ Level of Significance, we do not reject the null hypothesis, otherwise reject. *Significant at $1 \%$ level. 


\section{Discussion}

The purpose of the recent study is estimation of the incidence of irregular lipid levels (TC, TG, HDL, LDL) in those individuals who were living in the contaminant or industrial area and examine the association between serum lipids with persistent organic pollutant and risk of cardiovascular diseases.

The study of the National Health and Nutrition Examination Survey on women reported that there is a close relationship between cardiovascular diseases with plasma PCB levels (Ha et al., 2007). Previous studies reveal that several disorders such as insulin resistance, metabolic disorder (Lee et al., 2007) and diabetes mellitus (Wu et al., 2013) in humans are caused by exposure to PCBs and these disorders become the highest risk factor of cardiovascular disease.

Previous Studies explain PCBs is a major factor of death due to development of atherosclerotic wound and cardiovascular diseases (Arsenescu et al., 2008). Regardless of production having halted during the 1970s, polychlorinated biphenyls (PCBs) address constant natural poisons that keep on representing a genuine human wellbeing hazard. Exposure to PCBs has been associated to chronic inflammatory diseases, such as cardiovascular disease (Perkins et al., 2016; Gupta et al., 2018). Several OC pesticides were found to observed significant associations with metabolic syndrome in the Anniston study population while no association was observed for PCBs (Rosenbaum et al., 2017).

Current study describes the organochlorine pesticides and polychlorinated biphenyl compounds association with alteration in various serum lipid cholesterol levels. The present study result shows the human serum lipid parameters such as TC, TG and LDL-C level as increases while HDL-C level decreases in various concentrations. These concentrations are vary in different age groups such as mean result of TC is $66 \%, 78 \%$ and $73 \%$ in age groups and concluded that TC level is highest in middle group correspondingly TG was found as $91 \%, 78 \%$ and $89 \%$ in younger, middle and older groups.

Similarly 50\% increase LDL-C level found in younger and 685 in both middle and older persons. Previous studies reported that the nature of POPs are lipid soluble so these compounds regulate lipid and increase lipid weight but in the case of a cardiovascular disorder in contrast to the above statement numerous research on animal and human beings show lipid alteration due to these toxic pollutants (Lind and Lind, 2012,).

In the present investigation, TC and TG increase indirectly to age but LDL-C is inclining in age pattern. So we can say that those individuals who have high PCB concentrations may be at an increased risk of cardiovascular disorder.

Similar findings appear in our result as POPs mean concentration are increases in middle age group which also show TC and LDL-C level increase and HDL-C level $26 \%$ decrease as compare to other groups. Older groups also show second highest POPs concentration and their lipid results also show increase TC,TG and LDL-C then middle group but this group has highly decrease HDL-C as compare to middle age group.

In support to these observation Aminov explain in his study that elevated serum lipid may cause by high exposure of POPs particularly by chlorinated PCBs and some pesticides that become risk factors of CVD and obesity (Aminov et al., 2013). Similar study on U.S. general population demonstrated the strong association of POPs and risk of cardiovascular disorders (Ha et al., 2007). According to Mastin, POPs are the concerned probable risk factors of CVD because of their harmful effects on human health (Mastin, 2005). Researchers evaluate POPs burden, and its determinants, in a Spanish population at high risk of suffering CVD (Henríquez-Hernández et al., 2017).

Our outcome explains the lipid profile changes by a specific amount of pesticides also from a change in age, Systolic and diastolic blood pressure, and duration in a total of fifty serum samples. The alteration in lipid parameters may be due to the deposition of pesticides in body fat tissues. Among total studied individual who is calculated by logistic regression model average probability of TC the $76 \%$ increase. The average change in TG level by about $86 \%$. However, the present study shows an increased level of LDL-C about $62 \%$ which shows a significant change in lipid parameters.

Among the total sample, present results show HDL-C consequence decrease in male population as $34 \%$ and the female, it decreases 55\% the inference is clear that HDL-C decrease (counter effect) which show a strong relation to coronary heart disorder in that persons. Study of different scientists demonstrates that cardiovascular diseases and atherosclerosis may cause by due to abnormalities in lipid and lipoprotein (Goncharov et al., 2010).

Within this study, we found a positive association of organic residues with cardiovascular diseases. Our mean analysis of blood pressure (SBP) also shows increased percentages in all age groups in that sequence like $100 \%$, $89 \%$, and $84 \%$ according to age groups. Maximum increase level found in younger. Similarly, DBP also shows an increasing percentage in each group by following manners $25 \%, 47 \%$, and $31 \%$, in short, we can say that in presence of these results middle groups has high diastolic blood pressure level which may be another possible risk of cardiovascular disorder. The report of Goncharov explains that a contributing factor for hypertension and blood pressure is PCBs exposure and it shows a strong association with these parameters. Further he explain that increase rate of hypertension found in Anmiston Albama residents that is the major risk factor of CVD. (Goncharov et al., 2010). In previous study, conducted in middle aged men and women observed association of POPs with BP levels. Risk of hypertension showed with type of compounds along with total lipids in serum. All groups of this study showed positive relation with higher systolic and diastolic blood pressure (Donat-Vargas et al., 2018). Another study of cross sectional which has been conducted on Swedish elderly population, where 23 POPs were observed as a factor of hypertension, the strongest association was observed for DDE (Lind et al., 2014). 


\section{Conclusion}

The results of the current study show notable correlation between persistent organic pollutants and lipid profile factor that lead to risk of coronary heart diseases in Karachi. The study shows increased level in total cholesterol, triglyceride, and low-density lipoprotein and decrease level in high-density lipoprotein are related to increased concentration of pesticides (PCBs and OCs) and these observations indicate pollutant is found in the environment and highly exposed to these toxic chemical show significant increase threat of cardiovascular diseases. Further research can be performed by adjusting more variable with exposure of persistent organic pollutants and high risk of CVD.

\section{References}

AHMAD, K., 2002. Facing up to Pakistan's cardiovascular challenge. Lancet, vol. 359, no. 9309, pp. 859. http://dx.doi.org/10.1016/ S0140-6736(02)07983-7. PMid:11897296.

AMINOV, Z., HAASE, R.F., PAVUK, M. and CARPENTER, D.O., 2013. Analysis of the effects of exposure to polychlorinated biphenyls and chlorinated pesticides on serum lipid levels in residents of Anniston, Alabama. Environmental Health, vol. 12, no. 1, pp. 108. http://dx.doi.org/10.1186/1476-069X-12-108. PMid:24325314.

ANAND, S.S., ISLAM, S., ROSENGREN, A., FRANZOSI, M.G., STEYN, K., YUSUFALI, A.H., KELTAI, M., DIAZ, R., RANGARAJAN, S. and YUSUF, S., 2008. Risk factors for myocardial infarction in women and men: insights from the INTERHEART study. European Heart Journal, vol. 29, no. 7, pp. 932-940. http://dx.doi.org/10.1093/ eurheartj/ehn018. PMid:18334475.

ARSENESCU, V., ARSENESCU, R.I., KING, V., SWANSON, H. and CASSIS, L.A., 2008. Polychlorinated biphenyl-77 induces adipocyte differentiation and proinflammatory adipokines and promotes obesity and atherosclerosis. Environmental Health Perspectives, vol. 116, no. 6, pp. 761-768. http://dx.doi.org/10.1289/ehp.10554. PMid: 18560532 .

BEAGLEHOLE, R. and BONITA, R., 2008. Global public health: a scorecard. Lancet, vol. 372, no. 9654, pp. 1988-1996. http:// dx.doi.org/10.1016/S0140-6736(08)61558-5. PMid:18945485.

CARPENTER, D.O., 2008. Environmental contaminants as risk factors for developing diabetes. Reviews on Environmental Health, vol. 23, no. 1, pp. 59-74. http://dx.doi.org/10.1515/ REVEH.2008.23.1.59. PMid:18557598.

DONAT-VARGAS, C., ÅKESSON, A., TORNEVI, A., WENNBERG, M., SOMMAR, J., KIVIRANTA, H., RANTAKOKKO, P. and BERGDAHL, I.A., 2018. Persistent organochlorine pollutants in plasma, blood pressure, and hypertension in a longitudinal study. Hypertension, vol. 71, no. 6, pp. 1258-1268. http://dx.doi. org/10.1161/HYPERTENSIONAHA.117.10691. PMid:29712742.

FRÍAS, M.M., TORRES, M.J., FRENICH, A.G., MARTÍNEZ VIDAL, J.L., OLEA-SERRANO, F. and OLEA, N., 2004. Determination of organochlorine compounds in human biological samples by GC-MS/MS. Biomedical Chromatography, vol. 18, no. 2, pp. 102-111. http://dx.doi.org/10.1002/bmc.300. PMid:15039962.

GOENKA, S., PRABHAKARAN, D., AJAY, V.S. and REDDY, K.S., 2009. Preventing cardiovascular disease in India-translating evidence to action. Current Science, vol. 97, pp. 367-377.

GONCHAROV, A., BLOOM, M., PAVUK, M., BIRMAN, I. and CARPENTER, D.O., 2010. Blood pressure and hypertension in relation to levels of serum polychlorinated biphenyls in residents of
Anniston, Alabama. Journal of Hypertension, vol. 28, no. 10, pp. 2053-2060. http://dx.doi.org/10.1097/HJH.0b013e32833c5f3e. PMid:20644494.

GUPTA, P., THOMPSON, B.L., WAHLANG, B., JORDAN, C.T., HILT, J.Z., HENNIG, B. and DZIUBLA, T., 2018. The environmental pollutant, polychlorinated biphenyls, and cardiovascular disease: a potential target for antioxidant nanotherapeutics. Drug Delivery and Translational Research, vol. 8, no. 3, pp. 740-759. http://dx.doi.org/10.1007/s13346-017-0429-9. PMid:28975503.

HA, M.H., LEE, D.H. and JACOBS JUNIOR, D.R., 2007. Association between serum concentrations of persistent organic pollutants and self-reported cardiovascular disease prevalence: results from the National Health and Nutrition Examination Survey, 1999-2002. Environmental Health Perspectives, vol. 115, no. 8, pp. 1204-1209. http://dx.doi.org/10.1289/ehp.10184. PMid: 17687448.

HENRÍQUEZ-HERNÁNDEZ, L.A., LUZARDO, O.P., ZUMBADO, M., SERRA-MAJEM, L., VALERÓN, P.F., CAMACHO, M., ÁLVAREZ-PÉREZ, J., SALAS-SALVADÓ, J. and BOADA, L.D., 2017. Determinants of increasing serum POPs in a population at high risk for cardiovascular disease. Results from the PREDIMED-CANARIAS study. Environmental Research, vol. 156, pp. 477-484. http:// dx.doi.org/10.1016/j.envres.2017.03.053. PMid:28415042.

LEE, D.H., LEE, I.K., PORTA, M., STEFFES, M. and JACOBS JUNIOR, D.R., 2007. Relationship between serum concentrations of persistent organic pollutants and the prevalence of metabolic syndrome among non-diabetic adults: results from the National Health and Nutrition Examination Survey 1999-2002. Diabetologia, vol. 50, no. 9, pp. 1841-1851. http://dx.doi.org/10.1007/s00125007-0755-4. PMid:17624515.

LIND, L. and LIND, P.M., 2012. Can persistent organic pollutants and plastic-associated chemicals cause cardiovascular disease? Journal of Internal Medicine, vol. 271, no. 6, pp. 537-553. http:// dx.doi.org/10.1111/j.1365-2796.2012.02536.x. PMid:22372998.

LIND, P.M., PENELL, J., SALIHOVIC, S., VAN BAVEL, B. and LIND, L., 2014. Circulating levels of p, p' DDE are related to prevalent hypertension in the elderly. Environmental Research, vol. 129, pp. 27-31. http://dx.doi.org/10.1016/j.envres.2013.12.003. PMid:24528999.

MASTIN, J.P., 2005. Environmental cardiovascular disease. Cardiovascular Toxicology, vol. 5, no. 2, pp. 91-94. http://dx.doi. org/10.1385/CT:5:2:091. PMid:16046786.

PARK, M., LEE, S.K., YANG, J.Y., KIM, K.W., LEE, S.Y., LEE, W.T., CHUNG, K.H., YUN, Y.P. and YOO, Y.C., 2005. Distribution of organochlorines and PCB congeners in Korean human tissues. Archives of Pharmacal Research, vol. 28, no. 7, pp. 829-838. http:// dx.doi.org/10.1007/BF02977350. PMid:16114499.

PERKINS, J.T., PETRIELLO, M.C., NEWSOME, B.J. and HENNIG, B., 2016. Polychlorinated biphenyls and links to cardiovascular disease. Environmental Science and Pollution Research International, vol. 23, no. 3, pp. 2160-2172. http://dx.doi.org/10.1007/s11356-0154479-6. PMid:25877901.

REHAN, F., QADEER, A., BASHIR, I. and JAMSHAID, M., 2016. Risk factors of cardiovascular disease in developing countries. International Current Pharmaceutical Journal, vol. 5, no. 8, pp. 69-72. http://dx.doi.org/10.3329/icpj.v5i8.28875.

ROSENBAUM, P.F., WEINSTOCK, R.S., SILVERSTONE, A.E., SJÖDIN, A. and PAVUK, M., 2017. Metabolic syndrome is associated with exposure to organochlorine pesticides in Anniston, AL, United States. Environment International, vol. 108, pp. 11-21. http://dx.doi.org/10.1016/j.envint.2017.07.017. PMid:28779625.

WORLD HEALTH ORGANIZATION - WHO, 2013. WHO methods and data sources for global causes of death 2000-2011. Geneva: WHO. 
Khwaja, S. et al.

WU, H., BERTRAND, K.A., CHOI, A.L., HU, F.B., LADEN, F., GRANDJEAN, P. and SUN, Q., 2013. Persistent organic pollutants and type 2 diabetes: a prospective analysis in the nurses' health study and meta-analysis. Environmental Health Perspectives, vol. 121, no. 2, pp. 153-161. http://dx.doi.org/10.1289/ehp.1205248. PMid:23131992.
YUSUF, S., REDDY, S., ÔUNPUU, S. and ANAND, S., 2001. Global burden of cardiovascular diseases: part I: general considerations, the epidemiologic transition, risk factors, and impact of urbanization. Circulation, vol. 104, no. 22, pp. 2746-2753. http:// dx.doi.org/10.1161/hc4601.099487. PMid:11723030. 